\title{
IMPLIKASI MANAJERIAL NILAI TAMBAH PRODUK SUSU PASTEURISASI, SUSU STERILISASI \& KEJU MOZZARELLA PT. GREENFIELDS INDONESIA TERHADAP VOLUME PRODUKSI (Production Volume \& Production Value)
}

\author{
${ }^{1)}$ Yeyen Irawati ${ }^{2)}$ Nur Hidayat ${ }^{3)}$ Sucipto \\ 1. Mahasiswa Fakultas Teknologi Pertanian, Universitas Brawijaya, Malang. \\ yeyenirawatiunbraw@gmail.com. \\ 2. Dosen Fakultas Teknologi Pertanian, Universitas Brawijaya, Malang. \\ 3. Dosen Fakultas Teknologi Pertanian, Universitas Brawijaya, Malang.
}

\begin{abstract}
ABSTRAK
Penelitian bertujuan mengetahui nilai tambah produksi (product value added) produk susu pasteurisasi, susu sterilisasi \& produk keju Mozzarella PT. Greenfields Indonesia dengan menggunakan modifikasi Hayami Methods, melibatkan variabel GPM (Gross Profit Margin) menurut perspektif internal korporasi (perspektif proses) melibatkan variabel filling \& packing machine efficiency dan final product defect \& yield percentage dan perspektif eksternal korporasi (perspektif pasar) melibatkan variabel final product price serta mengetahui implikasi manajerialnya terhadap volume produksi (production volume \& production value) mengingat corporation policy menambah populasi Corporation Dairy Farm 600 ekor sapi Fressian Holstein (2015). Nilai tambah perspektif proses \& perspektif pasar (production volume \& production value) produk susu pasteurisasi 'Greenfields' plain milk $1000 \mathrm{ml}$ (2011, GPM 44,921\%) 366795,498 liter/periode (5,046\%) 9.794.173.186 Rp/periode (17.058 Rp/pack/periode), susu sterilisasi 'Greenfields' \& 'Fresh Natural' plain milk $1000 \mathrm{ml}$ (2014, GPM 63,885\%) 1211007,197 liter/periode (5,247\%) 22.862.834.354 Rp/periode (8.481 Rp/pack/periode); susu sterilisasi 'Real Good' flavoured milk $180 \mathrm{ml}$ (2014, GPM 63,885\%) 70288,463 liter/periode (0,357\%) 1.048.973.465 Rp/periode (1.207 Rp/pack/periode) dan produk keju Mozzarella 'Greenfields' 1000gr, 330gr, 250gr, 200gr (2014, GPM 63,885\%) 2181,114 liter/periode (0,0265\%) 240.053 .832 Rp/periode (4.241 Rp/pack Mozzarella/periode) 289.157.056 Rp/periode (5.115 Rp/pack Shredded Mozzarella/periode). Implikasi manajerial nilai tambah produk terhadap production volume \& production value (2016, GPM 44,158\%), produk susu pasteurisasi \& susu sterilisasi implikasi positif production volume 108,564 \%/periode, production value tidak mengalami perubahan signifikan dan produk keju Mozzarella implikasi positif production volume 108,215 $\% /$ periode - 108,738 \%/periode production value mengalami perubahan signifikan 226,200 $\% /$ periode - 226,585 \%/periode. Prosentase nilai implikasi tersebut merepresentasikan juga nilai implikasi positif penyediaan raw material input produksi (raw milk procurement) Corporation Dairy Farm PT. Greenfields Indonesia.
\end{abstract}

Keywords: Product Value Added, Production Volume \& Production Value, Gross Profit Margin, Hayami Methods

\begin{abstract}
Research is dedicated to obtain product value added of Greenfields Indonesia's pasteurized milk, sterilized milk \& Mozzarella cheese, using Hayami Methods modification deals with Gross Profit Margin (GPM) variable, according to internal corporate perspectives (process perspectives) involving filling \& packing machines efficiency, final product defect \& yield percentage and external corporate perspectives (market perspectives) involving final product price also figure out it's managerial implication to corporation's production both in production volume \& production value as consequence of the corporation policy increasing in amount of 600 Fressian Holstein cows to Corporation Dairy Farm (2015). Process perspectives \& market perspectives product value added (production volume \& production value) 'Greenfields' plain milk $1000 \mathrm{ml}$ pasteurized milk (2011, GPM 44,921\%) 366795,498 litre/period (5,046\%)
\end{abstract}


9.794.193 Rp/period (17.058 Rp/pack/period), 'Greenfields' \& 'Fresh \& Natural' plain milk 1000 ml sterilized milk (2014, GPM 63,885\%) 1211007,197 litre/period (5,247\%) 22.862.834.354 $\mathrm{Rp} /$ period (8.481 Rp/pack/period), 'Real Good' flavoured milk $180 \mathrm{ml}$ sterilized milk (2014, GPM 63,885\%) 70288,463 litre/period (0,357\%) 1.048.973 Rp/period (1.207 Rp/pack/period) and 'Greenfields' 1000gr; 330gr; 300gr; 250gr; 200gr Mozzarella cheese (2014, GPM 63,885\%) 2181,114 litre/period (0,0265\%) 240.053.832 Rp/period (4.241 Rp/Mozzarella pack/period) 289.157.056 Rp/period (5.115 Rp/Shredded Mozzarella pack/period). Product value added managerial implication (production volume \& production value) $(2016$, GPM 44,158\%) shows that pasteurized milk \& sterilized milk both at $108,564 \%$ level of change in production volume \& constant level in production value and Mozzarella cheese at 108,215\% - 108,738\% level of change in production volume \& 226,200\% - 226,585\% significant level of change in production value. The percentage value also represents percentage value of raw milk procurement of Greenfields Indonesia's Corporation Dairy Farm.

Keywords: Product Value Added, Production Volume \& Production Value, Gross Profit Margin, Hayami Methods

\section{Pendahuluan}

Raw milk merupakan senyawa koloidal emulsi lemak dalam air yang secara intrinsik memiliki nilai superioritas, mengandung senyawa nutrisi (nutrient) seperti karbohidrat, protein, lemak, mineral dan vitamin sebagai zat konduktansi pertumbuhan, senyawa non nutrisi (nutricients) seperti antioksidan alami, zat aromatik alami dan zat warna alami dan senyawa kemanfaatan kesehatan (nutraceutical) seperti senyawa bioaktif dan senyawa imunitas. Nilai intrinsik superioritas tersebut sangat prospektus bagi aktivitas agroindustrri; industri namun sebagai bahan baku input produksi (raw material), raw milk memiliki resistansi rendah terhadap implikasi ekstrisik sehingga diperlukan postharvest handling \& technology sedemikian sehingga nilai intrinsik superioritas tersebut tidak berubah signifikan; meningkatkan daya simpan produk (shelf life product) raw milk; meningkatkan nilai tambah produk (product value added) raw milk, salah satunya dengan mentransformasi input raw milk menjadi output produk fast moving consumers goods “Drinking Milk” susu pasteurisasi ESL (Extended Shelf Life Product), susu sterilisasi LL (Long Life Product) dan produk keju Mozzarella (Mozzarella \& Shredded Mozzarella Cheese) sebagaimana aktivitas produksi PT. Greenfields Indonesia.

Raw milk sangat prospektus bagi aktivitas agroindustri/ industri domestik, secara garis besar dapat direpresentasikan menurut perspektif permintaan (demand perspectives) dan perspektif penawaran (supply perspectives). Demand perspectives, raw milk memiliki tendensi sinergitas dengan population growth, economic growth \& industrial activity growth. Indonesia sebagai negara dengan jumlah populasi terbesar ke-4; annual population growth 0,17\%-1,38\% (2014), jumlah populasi 255,4617 juta jiwa (2015) diproyeksi meningkat menjadi 271,0664 juta jiwa (2020), 284,8290 juta jiwa (2025), 296,4051 juta jiwa (2030) \& 305,6524 juta jiwa (2035) dengan annual economic growth 11,20\% (2008-2013) diproyeksi pada level yang tidak berubah signifikan hingga 2018, 
menjadi refleks stimulator konstruktif bagi meningkatnya permintaan raw milk \& derivate product bermutualism dengan aktivitas produksi berbasis raw milk \& derivated product. Annual agroindustrial activity growth produk food \& beverage 8,45\% (2015) diproyeksi menjadi 8,90\% (2017) dengan market share domestik fast moving consumers goods growth 68,40\%(2013) \& produk “Drinking Milk” kontributif sebesar 39,80-44,80\% (2008-2013) prospektus hingga level 48,60\% (2018) meliputi market share liquid milk 8,20\% (2008-2013) fresh milk 8,20\% diproyeksi stabil pada level 7,108,20\% (2013-2018) \& keju prospektus $12,50 \%$ meliputi $38 \%$ up-middle class \& $28 \%$ middle-down class. Annual industrial growth berbasis protein hewani 3,00-15,30\% (2008-2013) diekspektasi pada level perubahan positif signifikan hingga 2018 seiring kemajuan sistim distribusi, infrastruktur storage dan teknologi industri pengolahan (postharvest handling and technology) (Data Diolah, 2014). Supply perspectives, raw milk merupakan produksi domestik $20 \%$ dan produk import $80 \%$. Produksi domestik didominasi individual farm dengan kepemilikan rerata 5 milky cows. Produksi raw milk domestik bertaraf korporasi agroindustri skala besar mendominasi 10,00-11,60\% lebih tinggi daripada korporasi skala menengah. Penurunan level penawaran raw milk 7,30\% (2009-2013) diproyeksi menjadi 6,30\% (2013-2018). Prospektus raw milk menurut demand perspectives \& supply perspectives tersebut mengindikasikan peluang sekaligus tantangan bagi PT. Greenfields Indonesia untuk dapat lebih progressif setelah menguasai pangsa pasar (market share) domestik produk premium fresh milk $24,5 \%$ volume produksi (production volume) dan $38,4 \%$ nilai produksi (production value) (Forst and Sullivan, 2014).

PT. Greenfields Indonesia merupakan korporasi produsen produk premium fresh milk \& cheese berskala besar dengan Corporation Dairy Farm dengan kepemilikan 2604-2855 milky cows; annual average milky yield/ milky cow 9,0 -9,4 ton (8754,8638 liter/annual 9143,9689 liter/annual) atau setara dengan 23,9859-25,0523 liter/hari; annual raw milk production capacity mencapai nilai 21341 tons - 6669 tons atau setara dengan 22797665,3690 -26106031,1281 liter (2011-2014) dengan Annual Gross Profit Margin (GPM) 44,9291\% - 63,8840\% (Greenfields Annual Report, 2014). Corporation Compound Growth Rate sebesar 0,11697\% milky cows growth/day dengan 0,04984\% milk production/day (2011) menunjukkan proyeksi Corporation Compound Growth Rate 0,6802\% (2011) menjadi 0,4436\% (2012); 0,3974\% (2013); 0,2557\% (2014); 0,1147\% (2015) dan -0,0263\% (2016) milky cows growth/week. Hasil proyeksi tersebut kemudian menjadi sinergis dengan adanya corporation policy pada pertengahan 2015 dengan menambah populasi Corporation Dairy Farm 600 ekor sapi Fressian Holstein. Penelitian ini bertujuan mengetahui nilai tambah produk (product value added) fast moving 
consumer good "drinking milk" susu pasteurisasi ESL (Extended Shelf Life Product), susu sterilisasi LL (Long Life Product) dan produk keju Mozzarella (Mozzarella \& Shredded Mozzarella Cheese) produksi PT. Greenfields Indonesia dengan menggunakan modifikasi formulasi Hayami Methods yang melibatkan variabel GPM (Gross Profit Margin). Perspektif yang digunakan yaitu perspektif internal korporasi (perspektif proses) yang melibatkan variabel filling \& packing machine efficiency dan final product defect \& final product yield percentage dan perspektif eksternal korporasi (perspektif pasar) yang melibatkan variabel final product price dan mengetahui implikasi manajerial nilai tambah produk terhadap volume produksi (production volume and production value) berdasarkan atas corporation policy tersebut.

\section{Materi Dan Metode}

Metode penelitian merupakan metode studi pengkajian detail spesifik production system satu objek penelitian korporasi terpilih PT. Greenfields Indonesia, berdasarkan data support previous research (Deasy, 2012; Fadlilatul, 2012; Hidayat, dkk. 2012 ; Rizky, 2011; Fachrial dan Nurtama, 2011; Hariri, 2013; Nikita, 2015; Putra, 2014 ; Ramadhan, 2011; Setyabudi, 2011; Tiara, 2011 dan Widodo, 2011) dan data support internal korporasi Financial Statement Annual Report of JAPFA Corporation 2014 serta data support lain yang yang bersinergi dengan judul dan tujuan penelitian. Metode kalkulasi matematis penelitian merupakan modifikasi konsep nilai tambah produk Hayami Methods terhadap variabel GPM (Gross Profit Margin) bersinergi dengan perspektif internal korporasi (perspektif proses) melibatkan variabel filling and packing machine efficiency dan final product defect and final product yield percentage dan perspektif eksternal korporasi (perspektif pasar) melibatkan variabel final product price terhadap produk kajian penelitian yaitu produk susu pasteurisasi ESL (Extended Shelf Life Product) "Greenfields" plain milk 1000 ml, susu sterilisasi LL (Long Life Product) "Greenfields" plain milk $1000 \mathrm{ml}$ dan susu sterilisasi LL (Long Life Product) "Real Good"flavoured milk $180 \mathrm{ml}$ serta keju Mozzarella "Greenfields" 1000 gr, 330gr, 250gr, 200gr pada periode tertentu (Picture 1).

Nilai tambah produk (product value added) merupakan proses transformasi produk oleh produsen dari nilai kharakteristik asli; tempat, waktu, bentuk tertentu menjadi nilai kharakteristik yang lebih bernilai ekonomi karena lebih diminati konsumen sebagai konsekuensi pemenuhan kebutuhan dan keinginan (need \& want). Hayami Methods merupakan metode kalkulasi nilai tambah produk yang memiliki kemudahan dalam pemahaman dan penggunaan serta memberikan informasi lengkap mengenai hasil 


\section{Jurnal Sains Peternakan}

Vol 7 No 1, Juni 2019, 1-21

ISSN 2579-4450

kalkulasi serta dalam implementasinya dapat dimodifikasi sesuai kepentingan. Gross Profit Margin (GPM) merupakan variabel representasi profitabilitas fungsional internal korporasi secara sengaja (purposive) dipilih sebagai variabel modifikasi Hayami Methods mengingat penelitian diparadigmakan menjadi perspektif internal korporasi dan eksternal korporas. PT. Greenfields Indonesia, objek kajian penelitian sebagai internal korporasi menjalin kerjasama dengan PT. Austasia Food sebagai product distribution corporate dengan final product price determination authority sementara pihak manajemen internal korporasi memerlukan data support praktis bagi tujuan fungsional internal korporasi; fungsi produksi (production volume \& production value) mengingat final product price di pasar domestik khususnya modern retailer channels sangat variatif dan mengingat sistim ordering yang diaplikasikan pihak internal korporasi (sistim goods in order) PT. Greenfields Indonesia.

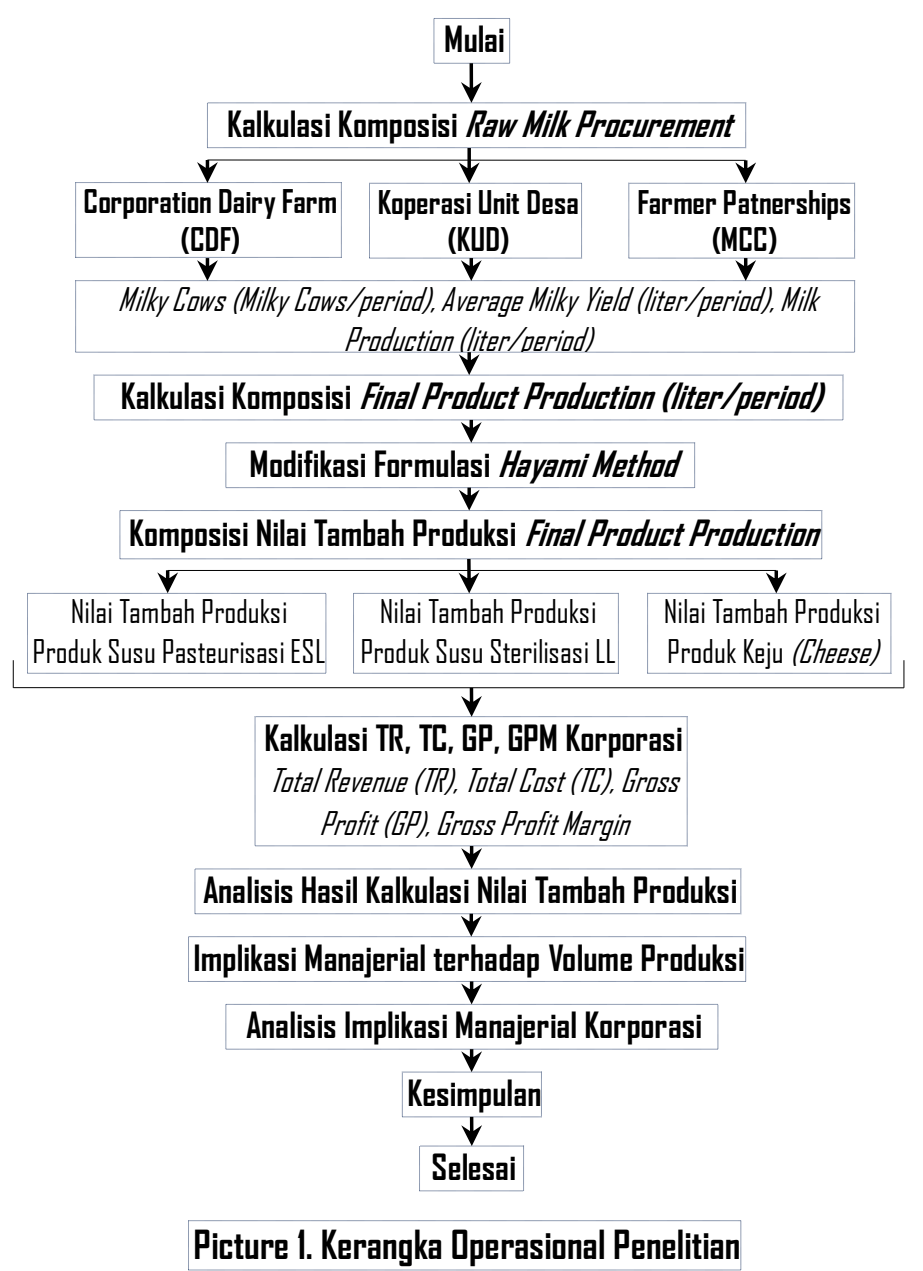

Formulasi Hayami Methods menyatakan nilai tambah produk (product value added) atau nilai tambah produksi suatu produk merupakan nilai product output yang 
dikurangi dengan product input price. Nilai product output merupakan faktor konversi dikalikan dengan product output price. Faktor konversi yaitu rasio perbandingan nilai product output terhadap product input yang dikalikan dengan final product price (Hayami et al., 1987 dalam Sudiyono, 2004). Faktor konversi tersebut merupakan formula efisiensi produksi. Konsep efisiensi didefinisikan kegiatan ekonomi mentransformasi input produksi menjadi output produksi dengan konsiderasi minimasi production cost, minimasi production waste meliputi efisiensi tool, raw material, raw waste and output quality, dan maksimasi kinerja proses. Efisiensi dapat ditinjau dari perspektif input dan perspektif output (Syamsi, 2004; Sinungan, 2009; Sumarsono, 2013). Secara matematis nilai tambah produksi final product output $X_{i(t)}$ pada periode ke $\mathrm{t} ; A V_{x i(t)}^{p}$ menurut konsep Hayami Methods dapat dinyatakan:

$$
\begin{aligned}
& A V_{x i(t)}^{p}=A V_{x i(t)}^{0}-\left[P_{x i(t)}^{i}+P_{x i(t)}^{(i+\cdots+n)}\right] \\
& A V_{x i(t)}^{p}=\left[E_{x i(t)}^{p} \cdot P_{x i(t)}^{0}\right]-\left[P_{x i(t)}^{i}+P_{x i(t)}^{(i+\cdots+n)}\right] \\
& A V_{x i(t)}^{p}=\left[\frac{Q_{x i(t)}^{0}}{Q_{x i(t)}^{i}} P_{x i(t)}^{0}\right]-\left[P_{x i(t)}^{i}+P_{x i(t)}^{(i+\cdots+n)}\right]
\end{aligned}
$$

dengan:

$$
\begin{array}{ll}
A V_{x i(t)}^{p} & : \text { Nilai tambah produksi final product } X_{i(t)} \\
A V_{x i(t)}^{0} & : \text { Nilai tambah output final product } X_{x i(t)} \\
P_{x i(t)}^{i} & : \text { Harga input produksi final product } X_{i(t)} \\
P_{x i(t)}^{p(i+\cdots+n)} & : \text { Harga input produksi i ke } \mathrm{n} \text { final product } X_{i(t)} \\
P_{x i(t)}^{0} & : \text { Harga output final product } X_{i(t)} \\
E_{x i(t)}^{p} & : \text { Effisiensi produksi final product } X_{i(t)} \\
Q_{x i(t)}^{0} & : \text { Jumlah output produksi final product } X_{i(t)} \\
Q_{x i(t)}^{i} & : \text { Jumlah input produksi final product } X_{i(t)}
\end{array}
$$

Profitabilitas, representasi performansi korporasi (corporation performance) dapat dijabarkan secara ekonomi dengan Konsep GPM (Gross Profit Margin) dan NPM (Net Profit Margin). GPM merupakan rasio deskripsi profitabilitas korporasi dari nilai penjualan final product output, NPM merupakan rasio deskripsi profitabilitas korporasi setelah pajak terhadap nilai penjualan final product output. Semakin tinggi nilai GPM maka semakin tinggi profitabilitas korporasi; semakin rendah harga final product output (Sumarsono, 2013). Secara matematis GPM sebagai rasio deskripsi profitabilitas korporasi yaitu GPM produksi final product output $X_{i(t)}$ pada periode ke t; $G P M_{x i(t)}^{p}$ dapat dinyatakan: 
$G P M_{x i(t)}^{p}=\frac{\pi_{x i(t)}^{p}}{V_{x i(t)}^{s}}=\frac{\pi_{x i(t)}^{p}}{\left[Q_{x i(t)}^{0} \cdot P_{x i(t)}^{0}\right]}$

$G P M_{x i(t)}^{p}=\frac{\left[Q_{x i(t)}^{0} \cdot P_{x i(t)}^{0}\right]-C_{x i(t)}^{s}}{\left[Q_{x i(t)}^{0} \cdot P_{x i(t)}^{0}\right]}$

$\% G P M_{x i(t)}^{p}=\frac{\left[Q_{x i(t)}^{0} \cdot P_{x i(t)}^{0}\right]-C_{x i(t)}^{s}}{\left[Q_{x i(t)}^{0} \cdot P_{x i(t)}^{0}\right]} \cdot 100 \%$

dengan:

$G P M_{x i(t)}^{p}$ : Gross Profit Margin produksi final product $X_{i(t)}$

$\pi_{x i(t)}^{p} \quad$ : Profitabilitas produksi final product $X_{x i(t)}$

$V_{x i(t)}^{S} \quad$ : Nilai penjualan output final product $X_{i(t)}$

$P_{x i(t)}^{0} \quad$ : Harga output final product $X_{i(t)}$

$C_{x i(t)}^{s} \quad$ : Biaya penjualan produksi final product $X_{i(t)}$

$Q_{x i(t)}^{0} \quad$ : Jumlah output produksi final product $X_{i(t)}$

Formulasi modifikasi Hayami Methods tersebut diperoleh pada syarat $\left[\sum P_{x i(t)}^{i}+\right.$ $\left.\sum P_{x i(t)}^{(i+\cdots+n)}\right]$ dan $C_{x i(t)}^{s}$ konstan hingga periode tertentu dan nilai tambah produksi (production volume \& production value) final product output $X_{i(t)}$ merupakan deskripsi profitabilitas produksi $\pi_{x i(t)}^{p}$ yaitu GPM final product $X_{i(t)}$, dapat dinyatakan:

$$
\begin{aligned}
& A V_{x i(t)}^{p} A V_{v o l-p r o}^{\text {int-process }}=\left[\% G P M_{x i(t)}^{p} \cdot Q_{x i(t)}^{i}\right] \\
& A V_{x i(t)}^{p} A V_{v o l \text { pro }}^{\text {ext-market }}=\left[\% G P M_{x i(t)}^{p} \cdot Q_{x i(t)}^{i} \cdot P_{x i(t)}^{0}\right] \\
& A V_{x i(t)}^{p} A V_{\text {val-pro }}^{\text {int-process }}=\left[\% G P M_{x i(t)}^{p} \cdot \frac{Q_{x i(t)}^{0}}{Q_{x i(t)}^{i}}\right] \\
& A V_{x i(t)}^{p} A V_{v a l-p r o}^{\text {ext-market }}=\left[\% G P M_{x i(t)}^{p} \cdot \frac{Q_{x i(t)}^{0}}{Q_{x i(t)}^{i}} \cdot P_{x i(t)}^{0}\right]
\end{aligned}
$$

dengan:

$G P M_{x i(t)}^{p}$ : Gross Profit Margin produksi final product $X_{i(t)}$

$A V_{x i(t)}^{p} \quad$ : Nilai tambah produksi final product $X_{i(t)}$

$\pi_{x i(t)}^{p} \quad$ : Profitabilitas produksi final product $X_{x i(t)}$

$P_{x i(t)}^{0} \quad$ : Harga output final product $X_{i(t)}$

$Q_{x i(t)}^{0} \quad$ : Jumlah output produksi final product $X_{i(t)}$

$Q_{x i(t)}^{i} \quad$ : Jumlah input produksi final product $X_{i(t)}$ 


\section{Hasil Dan Pembahasan}

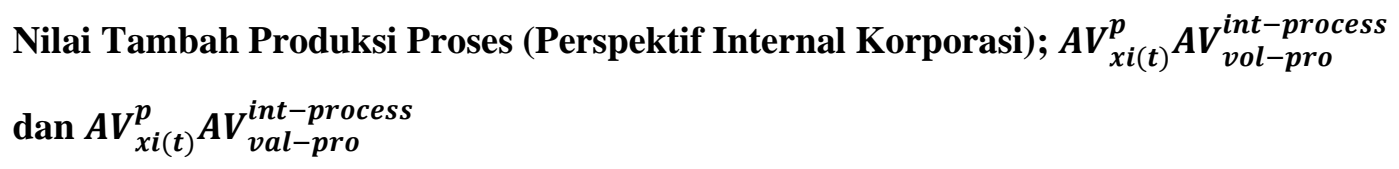

\section{Nilai Tambah Produk: Production Volume}

Nilai tambah produksi perspektif internal korporasi "on selected final product brand packing and selected period" menunjukkan bahwa nilai tambah produksi perspektif internal korporasi production volume merupakan hasil perkalian besaran raw milk production volume sebagai output produksi dengan Gross Profit Margin tanpa melibatkan harga raw milk baik sebagai input produksi maupun sebagai output produksi. Nilai tambah produksi perspektif internal korporasi production volume hanya dipengaruhi oleh besaran Gross Profit Margin dan tidak dipengaruhi oleh faktor nilai tukar raw milk baik sebagai input produksi maupun sebagai output produksi. Nilai tambah produksi perspektif internal korporasi production volume dinyatakan dalam satuan raw milk (liter/ periode) sebagai output produksi dan merupakan deskripsi nilai tambah volume produksi produk "on selected final product brand packing and selected period" korporasi.

Nilai tambah produksi perspektif internal korporasi production volume yang tidak melibatkan variabel harga raw milk baik sebagai input produksi maupun sebagai output produksi merupakan jenis kalkulasi nilai tambah produksi konsepsi intrinsik yang meliputi perspektif kuantitatif yang dinyatakan dalam besaran jumlah raw milk sebagai output produksi (liter selama periode) dan perspektif kualitatif yang dinyatakan dalam besaran persentase Gross Profit Margin. Nilai besaran yang didapat merupakan deskripsi besaran nilai tambah volume produksi raw milk sebagai output produksi (satuan liter selama periode) terhadap paradigma Gross Profit Margin sesuai Corporation Financial Statement on Annual Report 2014 atau besaran nilai tambah volume produksi raw milk sebagai output produksi tersebut kontributif terhadap besaran Gross Profit Margin korporasi.

Produk "Drinking Milk" susu sterilisasi plain milk $1000 \mathrm{~mL}$ "Greenfields \& Fresh Natural" (GPM 63,885\%) selama periode 31 Januari 2014 - 31 Mei 2014 memiliki besaran nilai tambah volume produksi (production volume) total kontributif (satuan liter) terhadap Gross Profit Margin sebesar 1211007,196 liter dan susu sterilisasi flavoured milk 180 mL "Real Good" (GPM 63,885\%) selama periode 31 Januari 2014 - 31 Mei 2014 memiliki besaran nilai tambah volume produksi (production volume) total kontributif (satuan liter) terhadap Gross Profit Margin sebesar 70288,463 liter dengan 
rincian kontribusi tiap produk. Produk "Drinking Milk" susu pasteurisasi plain milk 1000 mL "Greenfields" (GPM 44,921\%) selama periode 31 Januari 2011 - 31 Mei 2011 memiliki besaran nilai tambah volume produksi (production volume) total kontributif (satuan liter) terhadap Gross Profit Margin sebesar 366795,497 liter. Produk keju Mozzarella (mozzarella \& shredded mozzarella cheese) (GPM 63,885\%) 1000gr, 330 gr, 250gr, 200gr selama periode 31 Januari 2014 - 31 Mei 2014 memiliki besaran nilai tambah volume produksi (production volume) total kontributif (liter) terhadap Gross Profit Margin 2181,114 liter.

\section{Nilai Tambah Produk: Production Value}

Nilai tambah produksi perspektif internal korporasi korporasi "on selected final product brand packing and selected period" menunjukkan bahwa nilai tambah produksi perspektif internal korporasi korporasi production value merupakan hasil perkalian besaran raw milk efficiency produk dengan besaran Gross Profit Margin. Besaran raw milk efficiency and productivity merupakan hasil pembagian antara raw milk sebagai output produksi dengan raw milk sebagai input produksi (satuan liter selama periode) yaitu total raw milk procurement dari Corporation Dairy Farm (CDF), Farmers Patnerships (MCC) dan Koperasi Unit Desa (KUD). Nilai tambah produksi perspektif internal korporasi production value dipengaruhi oleh perubahan besaran Gross Profit Margin korporasi dan fluktuasi manajemen internal korporasi terkait raw milk procurement sedemikian sehingga kalkulasi nilai tambah produksi perspektif internal korporasi dalam penelitian ini tidak melibatkan harga raw milk baik sebagai input produksi maupun sebagai output produksi mengingat kepentingan kalkulasi turunan perencanaan produksi praktis internal korporasi.

Nilai tambah produksi perspektif internal korporasi production value merupakan deskripsi nilai tambah nilai produksi "on selected final product brand packing and selected period" yang dinyatakan dalam satuan prosentase raw milk efficiency and productivity selama periode tersebut untuk setiap final product brand packing. Nilai tambah produksi perspektif internal korporasi production value yang tidak melibatkan harga raw milk baik sebagai input produksi maupun sebagai output produksi merupakan jenis kalkulasi nilai tambah produksi konsepsi intrinsik yang meliputi perspektif kuantitatif yang dinyatakan dalam besaran jumlah raw milk sebagai output produksi (satuan liter selama periode) dan perspektif kualitatif yang dinyatakan dalam besaran Gross Profit Margin dan prosentase raw milk efficiency and productivity selama periode tersebut untuk setiap final product brand packing. Nilai yang didapat merupakan 
deskripsi besaran nilai tambah nilai produksi raw milk sebagai output produksi (satuan liter selama periode) untuk setiap final product brand packing pada paradigma Gross Profit Margin sesuai Corporation Financial Statement on Annual Report 2014 atau besaran jumlah raw milk sebagai output produksi dan raw milk efficiency and productivity selama periode tersebut kontributif terhadap Gross Profit Margin korporasi.

Produk "Drinking Milk" susu sterilisasi plain milk $1000 \mathrm{~mL}$ "Greenfields \& Fresh Natural” (GPM 63,885\%) selama periode 31 Januari 2014 - 31 Mei 2014 memiliki besaran nilai tambah production value per final product brand packing kontributif (satuan \%) terhadap Gross Profit Margin sebesar 5,247 \% dan produk susu sterilisasi flavoured milk 180 mL "Real Good" (GPM 63,8847\%) selama periode 31 Januari 2014 - 31 Mei 2014 memiliki besaran nilai tambah production value per final product brand packing kontributif (satuan \%) terhadap Gross Profit Margin sebesar 0,357\%. Produk "Drinking Milk" susu pasteurisasi plain milk $1000 \mathrm{~mL}$ "Greenfields" (GPM 44,921\%) selama periode 31 Januari 2011 - 31 Mei 2011 memiliki besaran nilai tambah production value per final product brand packing kontributif (satuan \%) terhadap Gross Profit Margin sebesar 5,045 \%. Produk keju Mozzarella (mozzarella \& shredded mozzarella cheese) (GPM 63,885\%) 1000gr, 330gr, 250gr, 200gr selama periode 31 Januari 2014 - 31 Mei 2014 memiliki besaran nilai tambah production value per final product brand packing kontributif (satuan \%) terhadap Gross Profit Margin sama sebesar 0,0265\% (Tabel 1).

$\begin{array}{llll}\text { Nilai Tambah Produksi Market (Perspektif Eksternal Korporasi); } & \text { Kon } \\ A V_{x i(t)}^{p} A V_{\text {vol pro }}^{\text {ex-market }} \text { dan } A V_{x i(t)}^{p} A V_{v a l-\text { pro }}^{\text {ex-market }} & \end{array}$

\section{Nilai Tambah Produk: Production Volume}

Nilai tambah produksi perspektif eksternal korporasi "on selected final product brand packing and selected period" menunjukkan bahwa nilai tambah produksi perspektif eksternal korporasi production volume merupakan hasil perkalian besaran production volume final product brand packing dengan Gross Profit Margin dan harga final product per unit brand packing. Nilai tambah produksi perspektif eksternal korporasi production volume responsif terhadap perubahan besaran Gross Profit Margin dan perubahan harga final product per unit brand packing. Nilai tambah produksi perspektif eksternal korporasi production volume dinyatakan dalam satuan harga produk di pasar (Rp/periode) yaitu jumlah harga final product brand packing selama periode tersebut dan merupakan deskripsi nilai tambah volume produksi produk "on selected brand packing and selected period" kontributif terhadap Gross Profit Margin. Nilai tambah produksi perspektif eksternal korporasi production volume yang melibatkan variabel harga output produksi 


\section{Jurnal Sains Peternakan}

Vol 7 No 1, Juni 2019, 1-21

ISSN 2579-4450

yaitu harga final product per unit brand packing merupakan jenis kalkulasi nilai tambah produksi konsepsi ekstrinsik yang meliputi perspektif kuantitatif yang dinyatakan dalam besaran nilai tukar final product brand packing per periode tersebut dan harga final product brand packing per unit tersebut kontributif terhadap Gross Profit Margin dan perspektif kualitatif yang dinyatakan dalam besaran persentase Gross Profit Margin. Nilai tambah produksi perspektif eksternal korporasi production volume merupakan deskripsi besaran nilai tambah volume produksi final product brand packing ( $\mathrm{Rp} /$ periode) selama periode tersebut pada paradigma Gross Profit Margin sesuai Corporation Financial Statement on Annual Report 2014 atau besaran nilai tambah volume produksi tersebut (Rp/periode) kontributif terhadap GPM.

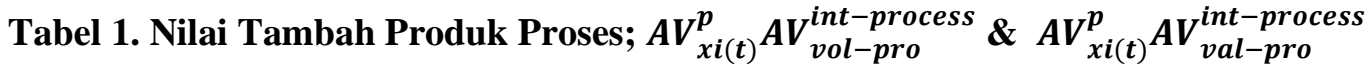

\begin{tabular}{|c|c|c|}
\hline $\begin{array}{l}\text { Final Product } \\
\text { Output } \\
X_{i(t)}\end{array}$ & 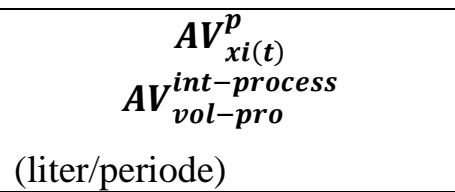 & $\begin{array}{c}A V_{x i(t)}^{p} \\
A V_{\text {val-pro }}^{\text {int-prose }} \\
(\% / \text { periode })\end{array}$ \\
\hline G 1000 LL HCSM & 70997,117 & 0,307 \\
\hline G 1000 LL LFHC & 255136,333 & 1,080 \\
\hline G 1000 LL FC & 597359,705 & 2,588 \\
\hline G 1000 LL WC & 161061,106 & 0,697 \\
\hline FN 1000 LL FHC & 53333,278 & 0,231 \\
\hline FN 1000 LL FC & 73119,655 & 0,316 \\
\hline RG 180 LL STRW & 70288,463 & 0,357 \\
\hline G 1000 ESL HCSM & 112550,097 & 1,548 \\
\hline G 1000 ESL FC & 254245,399 & 3,497 \\
\hline Mozzarella 1000 gr & 489,039 & 0,01187 \\
\hline Mozzarella 330 gr & 161,382 & 0,00391 \\
\hline Mozzarella $200 \mathrm{gr}$ & 195,615 & 0,00474 \\
\hline Mozzarella $250 \mathrm{gr}$ & 244,519 & 0,00593 \\
\hline Shredded 1000 gr & 489,039 & 0,01187 \\
\hline Shredded 330 gr & 161,382 & 0,00391 \\
\hline Shredded $200 \mathrm{gr}$ & 195,615 & 0,00474 \\
\hline Shredded $250 \mathrm{gr}$ & 244,519 & 0,00593 \\
\hline
\end{tabular}

Produk "Drinking Milk" susu sterilisasi plain milk $1000 \mathrm{~mL}$ "Greenfields \&Fresh Natural" (GPM 63,885\%) selama periode 31 Januari 2014 - 31 Mei 2014 memiliki besaran nilai tambah volume produksi (production volume) total kontributif (Rp/periode) terhadap Gross Profit Margin sebesar Rp. 22.862.834.354,- dan susu sterilisasi flavoured milk 180 mL "Real Good" (GPM 63,8847\%) selama periode 31 Januari 201431 Mei 2014 memiliki besaran nilai tambah volume produksi (production volume) total kontributif (Rp/periode) terhadap Gross Profit Margin sebesar Rp. 1.048.973.465,-. 
Produk "Drinking Milk" susu pasteurisasi plain milk $1000 \mathrm{~mL}$ "Greenfields" (GPM 44,921\%) selama periode 31 Januari 2011 - 31 Mei 2011 memiliki besaran nilai tambah volume produksi (production volume) total kontributif (Rp/periode)) terhadap Gross Profit Margin sebesar Rp. 9.794.173.686,-. Produk keju Mozzarella (Mozzarella \& Shredded Mozzarella Cheese) (GPM 63,885\%) 1000gr, 330gr, 250gr, 200gr selama periode 31 Januari 2014 - 31 Mei 2014 memiliki besaran nilai tambah volume produksi (production volume) total kontributif (Rp/periode) kontributif terhadap Gross Profit Margin sebesar Rp. 480.107.664,-.

\section{Nilai Tambah Produk: Production Value}

Nilai tambah produksi perspektif eksternal korporasi "on selected final product brand packing and selected period" menunjukkan bahwa nilai tambah produksi perspektif eksternal korporasi production value merupakan hasil perkalian besaran final product efficiency \& productivity dengan Gross Profit Margin dan harga per unit final product brand packing. Final product efficiency \& productivity merupakan representasi besaran machine efficiency yaitu besaran persentase akurasi mesin filling and packing dan prosentase final product defect per periode per final product brand packing tersebut untuk produk "Drinking Milk" susu pasteurisasi plain milk $1000 \mathrm{~mL}$ "Greenfields", susu sterilisasi plain milk $1000 \mathrm{~mL}$ "Greenfields \& Fresh Natural" dan susu sterilisasi flavoured milk $180 \mathrm{~mL}$ "Real Good" sementara untuk produk keju Mozzarella (Mozzarella \& Shredded Mozzarella Cheese) berbagai ukuran kemasan direpresentasikan oleh besaran cheese average yield (rendemen Final Product). Konsep ini sesuai dengan Hayami et al. (1987) bahwa nilai tambah produk dapat terjadi karena adanya "perlakuan proses" terhadap produk yang dalam hal ini proses filling and packing. Nilai tambah produksi perspektif eksternal korporasi production value responsif terhadap perubahan besaran Gross Profit Margin dan nilai tukar final product brand packing di pasar. Nilai tambah produksi perspektif eksternal korporasi production value merupakan deskripsi nilai tambah produk "on selected brand packing per unit final product output" (Rp/periode). Nilai tambah produksi perspektif eksternal korporasi production value yang melibatkan harga final product brand packing merupakan jenis kalkulasi nilai tambah produksi konsepsi ekstrinsik yang meliputi perspektif kuantitatif yang dinyatakan dalam besaran harga per unit final product brand packing dan perspektif kualitatif yang dinyatakan dalam besaran Gross Profit Margin. Nilai yang didapat memberikan deskripsi besaran nilai tambah nilai produksi per unit final product brand packing (Rp/periode) periode tersebut terhadap paradigma Gross Profit Margin sesuai Corporation Financial 
Statement on Annual Report 2014 atau besaran harga per unit final product brand packing (Rp/periode) tersebut kontributif terhadap besaran GPM.

Produk "Drinking Milk" susu sterilisasi plain milk $1000 \mathrm{~mL}$ "Greenfields \& Fresh Natural" (GPM 63,885\%) selama periode 31 Januari 2014 - 31 Mei 2014 memiliki besaran nilai tambah production value per final product brand packing kontributif (Rp/periode) terhadap Gross Profit Margin sebesar Rp. 8.481,- dan produk susu sterilisasi flavoured milk $180 \mathrm{~mL}$ "Real Good" (GPM 63,885\%) selama periode 31 Januari 2014 31 Mei 2014 memiliki besaran nilai tambah production value per final product brand packing kontributif (Rp/periode) terhadap Gross Profit Margin sebesar Rp. 1.207,--. Produk "Drinking Milk" susu pasteurisasi plain milk 1000 mL"Greenfields" (GPM 44,921\%) selama periode 31 Januari 2011 - 31 Mei 2011 memiliki besaran nilai tambah production value per final product brand packing kontributif (Rp/periode) terhadap Gross Profit Margin sebesar Rp. 17.058,-. Produk keju Mozzarella (Mozzarella \& Shredded Mozzarella Cheese) (GPM 63,885\%) 1000gr, 330gr, 250 gr, 200gr selama periode 31 Januari 2014 - 31 Mei 2014 memiliki besaran nilai tambah production value per final product brand packing kontributif (Rp/periode) terhadap Gross Profit Margin Rp. 4.241,(Mozzarella Cheese) dan Rp. 5.115,- (Shredded Mozzarella Cheese) (Tabel 2).

\section{Implikasi Manajerial Nilai Tambah terhadap Volume Produksi}

Setiap korporasi memiliki target tujuan korporasi jangka pendek dan jangka panjang. Target tujuan jangka panjang merupakan representasi tujuan final korporasi yang bersimbiosis mutualisme dengan visi dan misi korporasi secara komprehensif; kewenangan pemimpin tertinggi korporasi.Tujuan jangka pendek merupakan representasi aplikatif tahapan implementasi menuju tujuan jangka panjang tersebut yang menjadi kewenangan para manajer korporasi. Dalam perjalanan menuju tujuan tersebut problem solving sangat penting namun dalam paradigm manajemen strategis korporasi, para manajer melakukan tindakan manajemen strategis baik perspektif proses, konteks dan konten guna meningkatkan performansi korporasi menuju tujuan jangka panjang keunggulan bersaing (competitive advantage) yaitu suatu kondisi profitabilitas rerata korporasi lebih tinggi dari pesaing (sustained competitive advantage); formulasi strategi dan implementasi menggunakan taktik tertentu, rencana sistematis, metode khusus baik strategi inovasi maupun strategi yang merupakan pembelajaran internal dan eksternal korporasi; melakukan resource based view yaitu menganalisis sumber daya (resources), kemampuan (capabilities) dan kompetensi (competence) yang menjadi sistem korporasi (Pearce dan Robinson, 1991). 


\begin{tabular}{|c|c|c|}
\hline $\begin{array}{l}\text { Final Product } \\
\text { Output } \\
X_{i(t)}\end{array}$ & $\begin{array}{c}\boldsymbol{A} \boldsymbol{V}_{\boldsymbol{x i ( t )}}^{\boldsymbol{p}} \\
\boldsymbol{A} \boldsymbol{V}_{\boldsymbol{v o l}-\boldsymbol{p r o}}^{\text {ext-market }} \\
(\mathrm{Rp} / \text { periode })\end{array}$ & $\begin{array}{r}\boldsymbol{A} \boldsymbol{V}_{\boldsymbol{x i ( t )}}^{\boldsymbol{p}} \\
\boldsymbol{A} \boldsymbol{V}_{\boldsymbol{v a l}-\text { pro }}^{\text {ext-market }} \\
\text { (Rp/periode) }\end{array}$ \\
\hline G 1000 LL HCSM & 1.340 .368 .026 & 8.481 \\
\hline G 1000 LL LFHC & 4.816 .767 .187 & 8.481 \\
\hline G 1000 LL FC & 11.277 .667 .082 & 8.481 \\
\hline G 1000 LL WC & 3.040 .703 .144 & 8.481 \\
\hline FN 1000 LL FHC & 1.006 .889 .080 & 8.481 \\
\hline FN 1000 LL FC & 1.380 .439 .835 & 8.481 \\
\hline RG 180 LL STRW & 1.048 .973 .465 & 1.207 \\
\hline G 1000 ESL HCSM & 3.005 .312 .805 & 17.058 \\
\hline G 1000 ESL FC & 6.788 .860 .881 & 17.508 \\
\hline Mozzarella 1000 gr & 107.647 .459 & 4.241 \\
\hline Mozzarella 330 gr & 35.523 .661 & 4.241 \\
\hline Mozzarella $200 \mathrm{gr}$ & 43.058 .983 & 4.241 \\
\hline Mozzarella 250 gr & 53.823 .729 & 4.241 \\
\hline Shredded 1000 gr & 129.828 .545 & 5.115 \\
\hline Shredded 330 gr & 42.843 .420 & 5.115 \\
\hline Shredded $200 \mathrm{gr}$ & 51.931 .418 & 5.115 \\
\hline Shredded $250 \mathrm{gr}$ & 64.914 .273 & 5.115 \\
\hline
\end{tabular}

Strategi korporasi menuju sustained competitive advantage dapat dilakukan melalui tiga strategi yaitu growth strategy, stability strategy and retrencement strategy. Berkaitan dengan penelitian nilai tambah produksi produk perspektif eksternal dan internal korporasi production volume and production value memiliki implikasi manajerial terhadap volume produksi dapat disimpulkan bahwa korporasi PT. Greenfields Indonesia telah melakukan strategi korporasi growth strategy. Strategi korporasi growth stragtegy meliputi integrasi vertikal dan horizontal. Strategi integrasi vertikal dapat dilakukan melalui strategi memperluas bisnis seperti pengambilalihan pemasok; dominasi rantai pasokan input raw material (backward integration) dan pengambilalihan pelanggan; dominasi rantai distribusi output final product (forward integration) dan memaksimalkan nilai tambah produksi production volume and production value. Strategi integrasi horizontal dapat dilakukan melalui strategi memperluas segmentasi pasar dan meningkatkan rentang lini produk di area distribusi produk baik melalui akuisisi; merger dengan tujuan mutual-sustained competitive advantage; beberapa korporasi melakukan diversifikasi dalam manajemen strategi korporasinya yaitu dengan menambah satu atau lebih bisnis baru dalam portofolio bisnis korporasi baik concentric diversification and unrelated diversification; conglomeration. 
PT. Greenfields Indonesia berkenaan dengan manajemen strategis korporasi growth strategy integrasi vertikal yang dapat dilakukan melalui strategi memperluas bisnis seperti pengambilalihan pemasok; dominasi rantai pasokan input raw material (backward integration) dan pengambilalihan pelanggan; dominasi rantai distribusi output final product (forward integration) dan memaksimalkan nilai tambah produksi production volume and production value, PT. Greenfields Indonesia merupakan korporasi dengan konsep kesatuan input - process - output yang bersinergi dengan sistem terkecil Koperasi Unit Desa (KUD) dan MCC (Farmer Patnership) dalam raw material procurement produk susu sapi segar; bahan baku (raw material) berbagai produk olahan susu seperti produk fast moving consumer goods "Drinking Milk" susu pasteurisasi ESL (Extended Shelf Life Product), susu sterilisasi LL (Long Life Product) dan keju (Cheese) maka strategi backward integration kemungkinan mendapatkan surrounding threat sehingga tendensi tidak mungkin dilakukan; PT. Greenfields Indonesia merupakan korporasi yang menjalin kerjasama dengan PT. Austasia Food dalam distribution authority produk sedemikian sehingga final product price authority ada pada pihak PT. Austasia Food, harga produk "Drinking Milk" susu pasteurisasi, susu sterilisasi dan keju Mozzarella korporasi di pasar domestic; modern retailer channels sangat variatif maka strategi forward integration kemungkinan tidak mungkin dilakukan.

PT. Greenfields Indonesia melakukan pilihan manajemen strategis memaksimalkan nilai tambah produksi production volume and production value, hasil kalkulasi Milky Cows, Average Milk Yield dan Milk Production periode 31 Januari 2016 hingga 31 Mei 2016 menunjukkan CAGR 6,599\%, CMGR 0,994\%, CWGR -0,0263\% dan CDGR 0,1169\%; menunjukkan bahwa pada kalkulasi estimasi mingguan terdapat adanya defisiensi raw milk procurement Corporation Dairy Farm (CDF) pada pertengahan tahun 2016 yaitu mulai pada 30 April 2016 pihak korporasi melakukan strategi korporasi (corporation policy) menambah jumlah populasi Corporation Dairy Farm 600 ekor sapi Fressian Holstein pada pertengahan tahun 2015 yaitu setahun sebelum defisiensi produktivitas raw milk procurement diproyeksikan terjadi guna tujuan sustained competitive advantage korporasi. Strategi korporasi growth strategy tersebut langkah strategis korporasi memaksimalkan nilai tambah produksi production volume and production value. Penelitian ini menemukan bahwa terdapat implikasi manajerial nilai tambah produksi perspektif eksternal dan internal korporasi terhadap produksi produk korporasi (production volume \& production value) akibat strategi korporasi (corporation policy) tersebut, sebagai berikut: 
Produk Premium Milk "Drinking Milk" Susu Pasteurisasi ESL (Extended Shelf Life) Plain Milk 1000 Ml "Greenfields":

Nilai tambah produksi perspektif eksternal korporasi (perspektif pasar), production volume perubahan positif $108,564 \%$ production value tidak mengalami perubahan $\mathrm{Rp}$. 17.508;-.Nilai tambah produksi perspektif internal korporasi (perspektif proses), production volume mengalami perubahan positif $108,564 \%$ production value tidak mengalami perubahan.

Produk Premium Milk "Drinking Milk" Susu Sterilisasi LL (Long Life) Plain Milk 1000 Ml "Greenfields \&Fresh Natural":

Nilai tambah produksi perspektif eksternal korporasi (perspektif pasar), production volume mengalami perubahan positif $108,564 \%$ production value tidak mengalami perubahan Rp. 8.481;-.Nilai tambah produksi perspektif internal korporasi (perspektif proses), production volume mengalami perubahan positif $108,564 \%$ production value tidak mengalami perubahan.

Produk Premium Milk "Drinking Milk" Susu Sterilisasi LL Flavoured Milk 180 Ml "Real Good":

Nilai tambah produksi perspektif eksternal korporasi (perspektif pasar), production volume mengalami perubahan positif $108,564 \%$ production value tidak mengalami perubahan Rp. 1.207;-. Nilai tambah produksi perspektif internal korporasi (perspektif proses), production volume mengalami perubahan positif $108,564 \%$ production value tidak mengalami perubahan.

Produk Keju Mozzarella (Mozzarella and Shredded Mozzarella Cheese) 1000gr, 330 Gr, 250gr, 200gr:

Nilai tambah produksi perspektif eksternal korporasi (perspektif pasar), production volume mengalami perubahan positif rentang $108,211 \%$ - $108,738 \%$ production value tidak mengalami perubahan yaitu mozzarella Rp. 4.241;- dan Shredded Mozzarella Rp. 5.115;-. Nilai tambah produksi perspektif internal korporasi (perspektif proses), production volume mengalami perubahan positif $108,564 \%$ production value mengalami perubahan positif $226,200 \%-226,585 \%$.

Implikasi manajerial nilai tambah produk terhadap production volume \& production value, konsekuensi corporate policy penambahan populasi sapi Fressian Holstein 600 ekor (2015) sebagaimana Tabel 3 - Tabel 6 diperoleh hasil kalkulasi (2016, GPM 44,158\%), produk premium milk "Drinking Milk" susu pasteurisasi plain milk 1000 mL "Greenfields", susu sterilisasi plain milk 1000 mL "Greenfields \& Fresh Natural" dan susu sterilisasi flavoured milk $180 \mathrm{~mL}$ "Real Good" implikasi positif production volume $108,564 \% / p e r i o d e$, production value tidak mengalami perubahan signifikan dan produk 


\section{Jurnal Sains Peternakan}

Vol 7 No 1, Juni 2019, 1-21

ISSN 2579-4450

keju Mozzarella (Mozzarella and Shredded Mozzarella Cheese) 1000gr, 330gr, 250gr, $200 \mathrm{gr}$ implikasi positif production volume 108,215-108,738\%/periode, production value mengalami perubahan signifikan 226,200-226,585\%. Prosentase nilai implikasi tersebut merepresentasikan juga nilai implikasi positif penyediaan raw material input produksi (raw milk procurement) Corporation Dairy Farm PT. Greenfields Indonesia. Hasil tersebut dapat menjadi data support pengambilan keputusan manajerial perencanaan produksi berkaitan dengan volume produksi PT. Greenfields Indonesia jika korporasi memiliki keterbatasan dalam eksternal data support \& jika internal data support kurang bersinergi praktis dengan paradigma efisiensi manajemen strategis korporasi "sustained competitive advantage".

Tabel 3. Nilai Tambah Produk Proses; $A V_{x i(t)}^{p} A V_{\text {vol-pro }}^{\text {int-process }} \& A V_{x i(t)}^{p} A V_{\text {val-pro }}^{\text {int-process }}$ (Populasi ke-n)

\begin{tabular}{|c|c|c|}
\hline $\begin{array}{l}\text { Final Product } \\
\text { Output } \\
X_{i(t)}\end{array}$ & $\begin{array}{c}A V_{x i(t)}^{p} \\
\boldsymbol{A} \boldsymbol{V}_{\boldsymbol{v o l}-\text { pro }}^{\text {int-process }} \\
\text { (liter/periode) }\end{array}$ & $\begin{array}{c}A \boldsymbol{V}_{x i(t)}^{p} \\
\boldsymbol{A} \boldsymbol{V}_{\text {val-pro }}^{\text {int-process }}\end{array}$ \\
\hline G 1000 LL HCSM & 79314,644 & 0,302 \\
\hline G 1000 LL LFHC & 278702,573 & 1,062 \\
\hline G 1000 LL FC & 667342,208 & 2,395 \\
\hline G 1000 LL WC & 179929,903 & 0,685 \\
\hline FN 1000 LL FHC & 59581,434 & 0,227 \\
\hline FN 1000 LL FC & 81685,845 & 0,311 \\
\hline RG 180 LL STRW & 64742,624 & 0,247 \\
\hline G 1000 ESL HCSM & 277944,353 & 1,070 \\
\hline G 1000 ESL FC & 627863,277 & 2,417 \\
\hline Mozzarella 1000 gr & 384,567 & 0,00820 \\
\hline Mozzarella 330 gr & 126,907 & 0,00271 \\
\hline Mozzarella 200 gr & 153,827 & 0,00328 \\
\hline Mozzarella $250 \mathrm{gr}$ & 192,283 & 0,00410 \\
\hline Shredded 1000 gr & 384,567 & 0,00820 \\
\hline Shredded 330 gr & 126,907 & 0,00271 \\
\hline Shredded $200 \mathrm{gr}$ & 153,827 & 0,00328 \\
\hline Shredded 250 gr & 192,283 & 0,00410 \\
\hline
\end{tabular}


Tabel 4. Nilai Tambah Produk Proses; $A V_{x i(t)}^{p} A V_{v o l-p r o}^{\text {int-process }} \& A V_{x i(t)}^{p} A V_{\text {val-pro }}^{\text {int-process }}$ (Populasi ke-(n+600))

\begin{tabular}{|c|c|c|}
\hline $\begin{array}{l}\text { Final Product } \\
\text { Output } \\
X_{i(t)}\end{array}$ & $\begin{array}{c}A \boldsymbol{V}_{x i(t)}^{\boldsymbol{p}} \\
\boldsymbol{A} \boldsymbol{V}_{\boldsymbol{v o l}-\text { pro }}^{\text {int-process }} \\
\text { (liter/periode) } \\
\end{array}$ & $\begin{array}{c}A V_{x i(t)}^{p} \\
A V_{\text {val-pro }}^{\text {int-process }} \\
(\% / \text { periode }) \\
\end{array}$ \\
\hline G 1000 LL HCSM & 86107,077 & 0,302 \\
\hline G 1000 LL LFHC & 302570,403 & 1,062 \\
\hline G 1000 LL FC & 724492,776 & 2,395 \\
\hline G 1000 LL WC & 195338,933 & 0,685 \\
\hline FN 1000 LL FHC & 64683,933 & 0,227 \\
\hline FN 1000 LL FC & 88681,345 & 0,311 \\
\hline RG 180 LL STRW & 70287,122 & 0,247 \\
\hline G 1000 ESL HCSM & 301747,249 & 1,070 \\
\hline G 1000 ESL FC & 681632,906 & 2,417 \\
\hline Mozzarella 1000 gr & 417,501 & 0,01858 \\
\hline Mozzarella 330 gr & 137,775 & 0,00613 \\
\hline Mozzarella 200 gr & 167,000 & 0,00743 \\
\hline Mozzarella 250 gr & 208,750 & 0,00929 \\
\hline Shredded 1000 gr & 417,501 & 0,01858 \\
\hline Shredded 330 gr & 137,775 & 0,00613 \\
\hline Shredded $200 \mathrm{gr}$ & 167,000 & 0,00743 \\
\hline Shredded 250 gr & 208,750 & 0,00929 \\
\hline
\end{tabular}

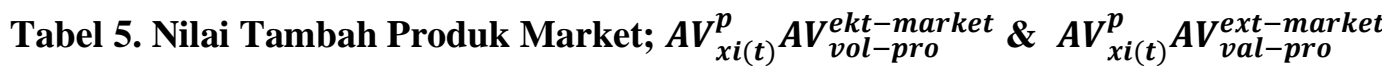
(Populasi ke-n)

\begin{tabular}{|c|c|c|}
\hline $\begin{array}{l}\text { Final Product } \\
\text { Output } \\
X_{i(t)}\end{array}$ & $\begin{array}{c}\boldsymbol{A V _ { x i ( t ) } ^ { \boldsymbol { p } }} \\
\boldsymbol{A} \boldsymbol{V}_{\boldsymbol{v o l}-\boldsymbol{p r o}}^{\boldsymbol{e x t - \text { market }}}\end{array}$ & $\begin{array}{c}\boldsymbol{A V _ { x i ( t ) } ^ { p }} \\
\boldsymbol{A} \boldsymbol{V}_{\text {val-pro }}^{\boldsymbol{e x t}-\boldsymbol{\text { market }}} \\
(\mathrm{Rp} / \text { periode })\end{array}$ \\
\hline G 1000 LL HCSM & 1.627 .338 .925 & 8.481 \\
\hline G 1000 LL LFHC & 5.718.285.849 & 8.481 \\
\hline G 1000 LL FC & 13.692 .193 .170 & 8.481 \\
\hline G 1000 LL WC & 3.691 .714 .942 & 8.481 \\
\hline FN 1000 LL FHC & 1.222 .465 .386 & 8.481 \\
\hline FN 1000 LL FC & 1.675 .993 .184 & 8.481 \\
\hline RG 180 LL STRW & 1.050 .011 .582 & 1.207 \\
\hline G 1000 ESL HCSM & 8.146.874.310 & 17.058 \\
\hline G 1000 ESL FC & 18.403.416.959 & 17.508 \\
\hline Mozzarella 1000 gr & 130.695 .621 & 4.241 \\
\hline Mozzarella 330 gr & 14.222 .346 & 4.241 \\
\hline Mozzarella 200 gr & 10.464 .993 & 4.241 \\
\hline Mozzarella 250 gr & 16.322 .353 & 4.241 \\
\hline Shredded 1000 gr & 157.625 .852 & 5.115 \\
\hline Shredded 330 gr & 17.152 .904 & 5.115 \\
\hline Shredded 200 gr & 12.621 .337 & 5.115 \\
\hline Shredded 250 gr & 19.685 .624 & 5.115 \\
\hline
\end{tabular}




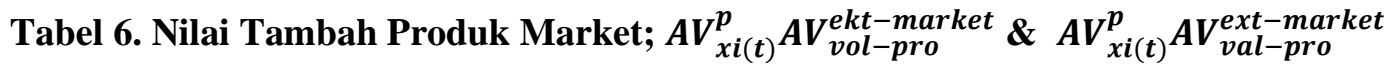
(Populasi ke-(n+600))

\begin{tabular}{|c|c|c|}
\hline $\begin{array}{l}\text { Final Product } \\
\text { Output } \\
X_{i(t)}\end{array}$ & 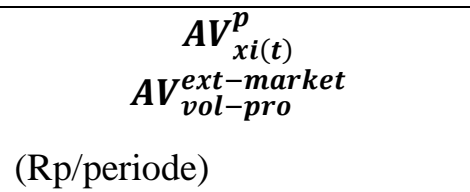 & $\begin{array}{c}\qquad \begin{array}{c}\boldsymbol{A} \boldsymbol{V}_{\boldsymbol{x i}(\boldsymbol{t})}^{\boldsymbol{p}} \\
\boldsymbol{A} \boldsymbol{V}_{\boldsymbol{v a l}-\boldsymbol{p r o}}^{\boldsymbol{x x t}-\text { market }}\end{array} \\
\text { (Rp/periode) }\end{array}$ \\
\hline G 1000 LL HCSM & 1.498 .968 .459 & 8.481 \\
\hline G 1000 LL LFHC & 5.267 .203 .282 & 8.481 \\
\hline G 1000 LL FC & 12.612 .101 .997 & 8.481 \\
\hline G 1000 LL WC & 3.400 .498 .754 & 8.481 \\
\hline FN 1000 LL FHC & 1.126 .033 .145 & 8.481 \\
\hline FN 1000 LL FC & 1.543 .783 .789 & 8.481 \\
\hline RG 180 LL STRW & 967.183 .114 & 1.207 \\
\hline G 1000 ESL HCSM & 7.504.224.919 & 17.058 \\
\hline G 1000 ESL FC & 16.951 .682 .440 & 17.508 \\
\hline Mozzarella 1000 gr & 120.417 .502 & 4.241 \\
\hline Mozzarella 330 gr & 13.143 .144 & 4.241 \\
\hline Mozzarella 200 gr & 9.624 .056 & 4.241 \\
\hline Mozzarella $250 \mathrm{gr}$ & 15.066 .787 & 4.241 \\
\hline Shredded 1000 gr & 145.229 .896 & 5.115 \\
\hline Shredded 330 gr & 15.851 .329 & 5.115 \\
\hline Shredded $200 \mathrm{gr}$ & 11.607 .123 & 5.115 \\
\hline Shredded $250 \mathrm{gr}$ & 18.171 .345 & 5.115 \\
\hline
\end{tabular}

\section{Kesimpulan}

Kesimpulan penelitian, nilai tambah perspektif proses \& perspektif pasar (production volume \& production value) produk susu pasteurisasi 'Greenfields' plain milk $1000 \mathrm{ml}$ (2011, GPM 44,921\%) 366795,498 liter/periode (5,046\%) 9.784.173.186 Rp/periode (17.058 Rp/pack/periode), susu sterilisasi 'Greenfields' \& 'Fresh Natural' plain milk $1000 \mathrm{ml}$ (2014, GPM 63,885\%) 1211007,197 liter/periode (5,247\%) 22.862.834.354 Rp/periode (8.481 Rp/pack/periode); susu sterilisasi 'Real Good' flavoured milk $180 \mathrm{ml}$ (2014, GPM 63,885\%) 70288,463 liter/periode (0,357\%) 1.048.973.465 Rp/periode (1.207 Rp/pack/periode) dan produk keju Mozzarella 'Greenfields' 1000gr, 330gr, 250gr, 200gr (2014, GPM 63,885\%) 2181,114 liter/periode (0,0265\%) 240.053.832 Rp/periode (4.241 Rp/pack Mozzarella/periode) 289.157.056 $\mathrm{Rp} /$ periode (5.115 Rp/pack Shredded Mozzarella/periode). Implikasi manajerial nilai tambah produk terhadap production volume \& production value (2016, GPM 44,158\%), produk susu pasteurisasi \& susu sterilisasi implikasi positif production volume $108,564 \%$ /periode production value tidak mengalami perubahan signifikan dan produk keju Mozzarella implikasi positif production volume 108,215-108,738\%/periode 
production value mengalami perubahan signifikan 226,200-226,585\%. Prosentase nilai implikasi tersebut merepresentasikan juga nilai implikasi positif penyediaan raw material input produksi (raw milk procurement) Corporation Dairy Farm PT. Greenfields Indonesia.

\section{UCAPAN TERIMAKASIH}

1. Dr. Ir. Nur Hidayat, MP., Dosen Jurusan Teknologi Industri Pertanian, Fakultas Teknologi Pertanian, Universitas Brawijaya, Malang.

2. Dr. Sucipto, STP. MP., Dosen Jurusan Teknologi Industri Pertanian, Fakultas

3. Teknologi Pertanian, Universitas Brawijaya, Malang.

4. Dr. Ir. Imam Santoso, MP., Dosen Jurusan Teknologi Industri Pertanian, Fakultas Teknologi Pertanian, Universitas Brawijaya, Malang.

5. Panji Deoranto, STP, PhD., Dosen Jurusan Teknologi Industri Pertanian, Fakultas Teknologi Pertanian, Universitas Brawijaya, Malang

\section{DAFTAR PUSTAKA}

Anditasari, Deasy. 2012. Manajemen Penanganan Bahan Baku dan Produk Jadi (Studi Kasus PT. Greenfields Indonesia, Malang). Jurusan Teknologi Industri Pertanian. Fakultas Teknologi Pertanian. Universitas Brawijaya, Malang.

Annisa, Fadlilatul. 2012. Pengendalian Mutu Produksi Susu UHT (Ultra High Temperature) Real Good Strawberry Secara Kualitatif (Studi Kasus PT. Greenfields Indonesia, Malang). Jurusan Teknologi Industri Pertanian. Fakultas Teknologi Pertanian. Universitas Brawijaya, Malang.

Danoza, E. Rizky. 2011. Analisis Sistem Pembuangan Limbah Pabrik Susu UHT (Ultra High Temperature) Real Good Strawberry (Studi Kasus PT. Greenfields Indonesia, Malang). Jurusan Teknologi Industri Pertanian. Fakultas Teknologi Pertanian. Universitas Brawijaya, Malang.

Fachrial, M dan Nurtama, B. 2011.Aplikasi Statistical Process Control (SPC) dalam Pengendalian Bobot Bersih Susu Ultra High Temperature (UHT) Real Good Sereal Strawberry PT. Greenfields Indonesia, Malang. Fakultas Teknologi Pertanian. IPB, Bogor.

Forst and Sullivan. 2014. Independent Market Research on Selected Market In Indonesia, China, India, Vietnam and Myanmar (Final Report). Singapore.

Gaspersz, Vincent. 2000. Manajemen Produktivitas Total, Strategi Peningkatan Produktivitas Bisnis Global. Edisi Revisi. PT. Gramedia Pustaka Utama. Jakarta.

Hariri, Rifan. 2013. Penerapan Metode Six Sigma Sebagai Upaya Perbaikan Untuk Mengurangi Pack Defect Susu Greenfields (Studi Kasus PT. Greenfields Indonesia, Malang). Skripsi. Jurusan Teknologi Industri Pertanian. Fakultas Teknologi Pertanian. Universitas Brawijaya, Malang.

Hidayat, Syarif, Marimin, A. Suryani, Sukardi, dan M. Yani. 2012. Modifikasi Metode Hayami Untuk Perhitungan Nilai Tambah Pada Rantai Pasok Agroindustri Kelapa Sawit. Institut Pertanian Bogor. Jurnal Teknologi Industri Pertanian, 22(1): 22-31. 
Nikita, Putri. 2015. Perancangan Tata Letak Penempatan Barang Gudang Penyimpanan Produk Jadi Melalui Penerapan Storage Policy (Studi Kasus PT. Greenfields Indonesia, Malang). Jurusan Teknik Industri. Fakultas Teknik. Universitas Brawijaya. Malang.

Pierce, J.A. dan Robinson, R.B. 1991.Strategic Management, Formulation, Implementation and Control. Fourth Edition. Richard D. Irwin, Inc. Boston: 237.

Putra, A. Maulana. 2014, Implementasi Program Corporate Social Responsibility (CSR) Berbasis Community Development (Studi Kasus PT. Greenfields Indonesia, Malang). Skripsi. Jurusan Ilmu Administrasi dan Bisnis.Fakultas Ekonomi dan Bisnis. Universitas Brawijaya, Malang.

Ramadhan, D.A. 2011. Manajemen Pemeliharaan Sapi Perah dan Pemerahan di PT. Greenfields Indonesia, Malang. Skripsi. Fakultas Peternakan. IPB, Bogor.

Sinungan, Muchdarsyah. 2009. Produktivitas. Cet. 8. Ed. 2. Bumi Aksara. Jakarta: 41-42.

Setyabudi, Agung. 2011.Analisis Penerapan Metode Six Sigma Untuk Mengurangi Kebocoran Akibat Pack Defect of Top Seal Pada Proses Filling Produksi Susu ESL $1000 \mathrm{~mL}$ Greenfields (Studi Kasus PT. Greenfields Indonesia, Malang). Jurusan Teknik Produksi. Fakultas Teknik Industri. Universitas Brawijaya, Malang.

Sudiyono, A. 2004. Pemasaran Pertanian. Penerbit UMM. Malang.

Sumarsono, Thomas. 2013. Sistem Pengendalian Manajemen: Konsep, Aplikasi dan Pengukuran Kinerja, Penerbit Graha Ilmu, I (2): 88-89.

Syamsi, Ibnu. S.U. 2004.Efisiensi, Sistem dan Prosedur Kerja. Penerbit Bumi Aksara. Edisi Revisi: 1-15.

Tiara, Theresia Dyan.2013. Kegiatan Kualitas Quality Assurance Validasi Efektivitas Rinsing Botol Produk Greenfields ESL 2000 mL (Studi Kasus PT. Greenfields Indonesia, Malang). Jurusan Teknologi Industri Pertanian. Fakultas Teknologi Pertanian. Universitas Brawijaya, Malang.

Umar, Husein. 2001. Evaluasi Kinerja Perusahaan. PT. Gramedia Pustaka Utama. Jakarta.

Wardhani Y. Firdausa. 2015. Analisis Produktivitas dan Waste Reduction dengan Pendekatan Metode Green Productivity. Fakultas Teknik. Konsentrasi Rekayasa Sistem Industri. Universitas Brawijaya. Malang.

Widodo, Beni. 2011. Analisis Penerapan Six Sigma Untuk Mengurangi Defect on Transversal Seal Bloked Pada Proses Filling Susu Real Good (Studi Kasus PT. Greenfields Indonesia, Malang). Jurusan Teknik Produksi. Fakultas Teknik Industri. Universitas Brawijaya, Malang. 